\title{
Editorial
}

\section{Special Issue on Smart Sustainable Manufacturing Systems}

\author{
Gökan May *(D) and Dimitris Kiritsis * \\ École Polytechnique Fédérale de Lausanne, ICT for Sustainable Manufacturing, EPFL SCI-STI-DK, Station 9, \\ 1015 Lausanne, Switzerland \\ * Correspondence: gokan.may@epfl.ch (G.M.); dimitris.kiritsis@epfl.ch (D.K.)
}

Received: 24 May 2019; Accepted: 27 May 2019; Published: 31 May 2019

check for updates

\section{Introduction}

With the advent of disruptive digital technologies, companies are facing unprecedented challenges and opportunities. Advanced manufacturing systems are of paramount importance in making key enabling technologies and new products more competitive, affordable and accessible as well as fostering their economic and social impact. The manufacturing industry also serves as an innovator for sustainability since automation coupled with advanced manufacturing technologies have helped to transition manufacturing practices to the circular economy [1]. In this context, shifting paradigms comprehend the 360-degree makeover of factories, from shop-floor to supply chain, from blue collar staff to top management, from employee to stakeholder. In that regard, the objective of smart and sustainable manufacturing systems of the future is to enable clean and competitive manufacturing systems irrespective of factories' location or size, and to find opportunities based on sustainability issues to grow beyond their borders [2]. To that end, this special issue of the journal Applied Sciences devoted to the broad field of Smart Sustainable Manufacturing Systems was introduced to explore recent research into the concepts, methods, tools and applications for smart sustainable manufacturing in order to advance and promote the development of modern and intelligent manufacturing systems.

\section{Smart Sustainable Manufacturing Systems}

In light of the above, this special issue collects the latest research on relevant topics, and addresses present challenging issues with the introduction of smart sustainable manufacturing systems. There were 24 papers submitted to this special issue, and 9 papers were accepted (i.e., a 37.5\% acceptance rate). Various topics have been addressed in this special issue, mainly on design of sustainable production systems and factories; industrial big data analytics and cyber physical systems; intelligent maintenance approaches and technologies for increased operating life of production systems; zero-defect manufacturing strategies, tools and methods towards on-line production management; and connected smart factories.

The first paper, Production and Maintenance Planning for a Deteriorating System with Operation-Dependent Defectives, authored by H. Rivera-Gómez, O. Montaño-Arango, J. Corona-Armenta, J. Garnica-González, E. Hernández-Gress, and I. Barragán-Vite provides new insights into the area of sustainable manufacturing systems by analysing the novel paradigm of integrated production logistics, quality and maintenance design, and investigates the optimal production and maintenance switching strategy of an unreliable deteriorating manufacturing system. The paper presents a model that defines the joint production and maintenance switching strategies minimizing the total cost over an infinite planning horizon [3].

The second paper, Kernel-Density-Based Particle Defect Management for Semiconductor Manufacturing Facilities, proposes a particle defect management method for the reduction of the 
defect ratio in semiconductor manufacturing facilities, and presents a kernel-density-based particle map that can overcome the limitations of the conventional method [4], authored by S. Park, S. Kim, and J.-G. Baek.

The third paper of the Special Issue, A Multi-Usable Cloud Service Platform: A Case Study on Improved Development Pace and Efficiency, authored by J. Lindström, A. Hermanson, F. Blomstedt, and P. Kyösti, addresses a micro small and medium-sized enterprise (SME) in Sweden and its journey of developing and operating a multi-usable cloud service platform for big data collection and analytics [5].

The article An Integrated Open Approach to Capturing Systematic Knowledge for Manufacturing Process Innovation Based on Collective Intelligence by G. Wang, Y. Hu, X. Tian, J. Geng, G. Hu, and M. Zhang [6] builds a novel holistic paradigm of process innovation knowledge capture based on collective intelligence as a foundation for the future knowledge-inspired computer-aided process innovation and smart process planning.

The next two articles focus on approaches and methods on supply chain level. The first one, A Modified Method for Evaluating Sustainable Transport Solutions Based on AHP and Dempster-Shafer Evidence Theory by L. Chen and X. Deng, presents a transport sustainability index (TSI) as a primary measure to determine whether transport solutions have a positive impact on city sustainability [7]. The subsequent paper, Dynamic Supply Chain Design and Operations Plan for Connected Smart Factories with Additive Manufacturing authored by B. Chung, S.I. Kim and J.S. Lee suggests a general planning framework and various optimization models for dynamic supply chain design and operations plan [8].

The seventh paper in this Special Issue, The Role of Managerial Commitment and TPM Implementation Strategies in Productivity Benefits written by J. Díaz-Reza, J. García-Alcaraz, L. Avelar-Sosa, J. Mendoza-Fong, J. Sáenz Diez-Muro, and J. Blanco-Fernández [9], proposes a structural equation model to integrate four latent variables: Managerial commitment, preventive maintenance, total productive maintenance, and productivity benefits.

Subsequently, Opportunities for Industry 4.0 to Support Remanufacturing by S. Yang, A.M.R., J. Kaminski, and H. Pepin reviews the challenges encountered by the remanufacturing sector and discusses how the Industry 4.0 revolution could help to effectively address these issues and unlock the potential of remanufacturing [10].

Last but not least, the final article Hybrid Laminate for Haptic Input Device with Integrated Signal Processing of R. Schmidt, A. Graf, R. Decker, V. Kräusel, W. Hardt, D. Landgrebe, and L. Kroll presents a new tool concept for joining and forming hybrid laminates in a manufacturing process [11].

\section{Future Research}

Although the special issue has been closed, more in-depth research in smart sustainable manufacturing systems is expected. In particular, demonstrative scenarios that pertain to smart design, smart machining, smart control, smart monitoring, and smart scheduling to highlight key enabling technologies and their possible applications to Industry 4.0 smart manufacturing systems could complement the research aspects covered within this Special Issue.

Acknowledgments: We would like to take this opportunity to thank all the authors, reviewers, and dedicated editorial team of Applied Sciences. The special issue would not have been possible without the contributions and generous support of them.

Conflicts of Interest: The authors declare no conflict of interest.

\section{References}

1. 2018 World Manufacturing Forum Report, Recommendations for the Future of Manufacturing. Available online: https://www.worldmanufacturingforum.org/report (accessed on 24 May 2019).

2. May, G.; Stahl, B.; Taisch, M. Energy management in manufacturing: Toward eco-factories of the future-A focus group study. Appl. Energy 2016, 164, 628-638. [CrossRef] 
3. Rivera-Gómez, H.; Montaño-Arango, O.; Corona-Armenta, J.; Garnica-González, J.; Hernández-Gress, E.; Barragán-Vite, I. Production and Maintenance Planning for a Deteriorating System with Operation-Dependent Defectives. Appl. Sci. 2018, 8, 165. [CrossRef]

4. Park, S.; Kim, S.; Baek, J.-G. Kernel-Density-Based Particle Defect Management for Semiconductor Manufacturing Facilities. Appl. Sci. 2018, 8, 224. [CrossRef]

5. Lindström, J.; Hermanson, A.; Blomstedt, F.; Kyösti, P. A Multi-Usable Cloud Service Platform: A Case Study on Improved Development Pace and Efficiency. Appl. Sci. 2018, 8, 316. [CrossRef]

6. Wang, G.; Hu, Y.; Tian, X.; Geng, J.; Hu, G.; Zhang, M. An Integrated Open Approach to Capturing Systematic Knowledge for Manufacturing Process Innovation Based on Collective Intelligence. Appl. Sci. 2018, 8, 340. [CrossRef]

7. Chen, L.; Deng, X. A Modified Method for Evaluating Sustainable Transport Solutions Based on AHP and Dempster-Shafer Evidence Theory. Appl. Sci. 2018, 8, 563. [CrossRef]

8. Chung, B.; Kim, S.I.; Lee, J.S. Dynamic Supply Chain Design and Operations Plan for Connected Smart Factories with Additive Manufacturing. Appl. Sci. 2018, 8, 583. [CrossRef]

9. Díaz-Reza, J.; García-Alcaraz, J.; Avelar-Sosa, L.; Mendoza-Fong, J.; Sáenz Diez-Muro, J.; Blanco-Fernández, J. The Role of Managerial Commitment and TPM Implementation Strategies in Productivity Benefits. Appl. Sci. 2018, 8, 1153. [CrossRef]

10. Yang, S.; MR, A.; Kaminski, J.; Pepin, H. Opportunities for Industry 4.0 to Support Remanufacturing. Appl. Sci. 2018, 8, 1177. [CrossRef]

11. Schmidt, R.; Graf, A.; Decker, R.; Kräusel, V.; Hardt, W.; Landgrebe, D.; Kroll, L. Hybrid Laminate for Haptic Input Device with Integrated Signal Processing. Appl. Sci. 2018, 8, 1261. [CrossRef]

(C) 2019 by the authors. Licensee MDPI, Basel, Switzerland. This article is an open access article distributed under the terms and conditions of the Creative Commons Attribution (CC BY) license (http://creativecommons.org/licenses/by/4.0/). 